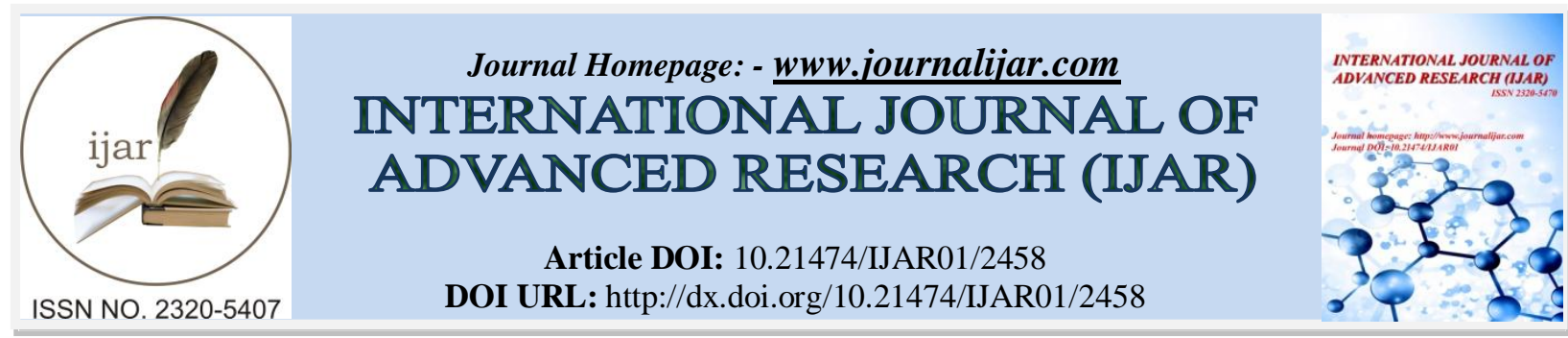

RESEARCH ARTICLE

\title{
ISOLATION, CHARACTERIZATION OF ACINETOBACTER BAUMANNII RESISTANT TO CARBAPENEM AND THEIR EFFECT ON MICE HEPATORENAL FUNCTIONS.
}

\author{
Mowafy E. $M^{\mathbf{1}}$, Serag H. $M^{\mathbf{1}}$, El Degla. H. $\mathrm{E}^{\mathbf{2}}$ and Edrees G. M. $\mathrm{F}^{\mathbf{1}}$. \\ 1. Zoology Department, Faculty of Science, Mansoura University. \\ 2. Medical Microbiology and Immunology Department, Faculty of Medicine, Mansoura University.
}

\section{Manuscript Info}

…......................

Manuscript History

Received: 23 October 2016

Final Accepted: 21 November 2016

Published: December 2016

\section{Abstract}

This study was carried out to illustrate multi-drug resistant Acinetobacter baumannii which have carbapenem resistance genes and to show its effect on mice hepatorenal functions. Forty four (4.2\%) A.baumannii strains were isolated from 1050 positive cultures of all nosocomial pathogens isolated from Mansoura University Hospitals over one year. Sensitivity rates of A.baumannii were (28\%) to imipinem, (66\%) to meropenem, and (50\%) to amikacin. Phenotypic detection of extended-spectrum ß-lactamases (ESBLs) was done by the Modified Hodge test which showed that (54.55\%) of A.baumannii were positive and $45.45 \%$ were negative. The bla $a_{O X A}$ genes were identified in A.baumannii by PCR analysis of which (72.72\%) were positive for $b l a_{O X A-23}$ gene and $(29.54 \%)$ were positive for $b_{1 a_{O X A-58}}$ gene. Statistically significant increase of mice liver function markers in serum of infected mice in group I (infected with resistant A.baumannii strain) and group II (infected with sensitive A.baumannii strain) in comparison to control group and the effect in the group I was higher than group II indicating that resistance genes may be accompanied by virulence genes. Regarding the renal function tests there were slight changes in the form decrease of creatinine and urea levels in infected mice in comparison to the control group with no statistically significant change. There were no considerable change in $\mathrm{Na}^{+}, \mathrm{K}^{+}$, and uric acid levels. Statistically significant decrease of Glutathione level (GSH) and in activities of superoxide dismutase (SOD) and catalase (CAT) were found in mice liver tissue in group I and II in comparison to control group.

It may be concluded that, A. baumannii infections in human need early detection, with restriction of the usage of carbapenems and improving infection-control procedures. The effect of A. baumannii infections in mice especially on liver functions, decrease immunity and disturb antioxidant balance.

Copy Right, IJAR, 2016,. All rights reserved.

\section{Introduction:-}

Acinetobacter spp. are aerobic, non-motile non fermentative coccobacilli which occur in pairs. They have emerged as important opportunistic pathogens, frequently occurring in critically ill intensive care unit (ICU) patients with 
prolonged hospitalizations or chronic illness. Outbreaks involving multidrug-resistant strains have occurred worldwide $^{(\mathbf{1 , 2})}$.

A. baumannii is resistant to the action of many antimicrobial drugs and spreads easily from patient to patient and survives desiccation. It persists in the environment for many days and causes extended epidemic outbreaks ${ }^{(3)}$. Severe infections by A.baumannii occurred in hospitalized patients such as pneumonia, skin infections, bacteremia, urinary tract infections, and meningitis, with an attributed mortality of 7.8 to $23 \%{ }^{(4)}$.

Carbapenemases may be defined as B-lactamases that significantly hydrolyze at least imipenem and/or meropenem. They are increasingly reported worldwide among nosocomial and community acquired Gram-negative bacilli ${ }^{(\mathbf{5})}$.The enzymatic degradation by carbapenemases is the most prevalent mechanism of carbapenem resistance in A.baumannii that include OXA-type and Metallo- $\beta$-lactamases (MBLs) ${ }^{(6)}$.

More specifically, acquired OXA-type carbapenem-hydrolyzing class D B-lactamases of the OXA-23, OXA-24/40 and OXA-58 subfamilies, and the intrinsic OXA-51-type is common among A.baumannii isolates ${ }^{(7)}$.

During sepsis, the liver plays a key role in regulating a wide range of key metabolic, homeostatic, and host-defense activities. It is implicated in the host response, participating in the clearance of the infectious agents/products. Sepsis also induces liver damage through hemodynamic alterations or through direct or indirect assault on the hepatocytes or through both $^{(8)}$.

The liver actively modulates the inflammatory processes by filtering, inactivating and clearing bacteria., bacterial product e.g endotoxin and the stimulated liver releases the highest amount of cytokines ${ }^{(9)}$. Acute renal failure (ARF) is the most common renal manifestation of sepsis and sepsis accounts wholly or in part, for more than $50 \%$ of cases of acute renal failure ${ }^{(\mathbf{1 0})}$.

Antioxidants are important in living organisms because they may delay or stop the formation of free radicals by giving hydrogen atoms or scavenging them. Severe sepsis leading to shock is the principle cause of death in ICUs. Immune cells use reactive oxygen species (ROS) in order to support their functions and need adequate levels of antioxidant defenses to avoid harmful effects of an excessive ROS production ${ }^{(11)}$.

The present work aims to evaluate carbapenem resistant genes in A.baumannii and to determine their toxic effect on excretory system in mice.

Patients and Methods:-

Patients and clinical samples: Sputum, urine, blood, wound swabs were collected from August 2013 to July 2014. The samples were collected from patients who were admitted to Mansoura University Hospitals (MUHs) and showing manifestations of hospital acquired infections.

\section{Processing of patient samples:-}

All collected samples were processed in the Microbiology Diagnostics and Infection Control Unit (MDICU) in medical microbiology and immunology department, Mansoura faculty of medicine according to the standard methods of microbiology and the unit policies.

\section{Culture:-}

Samples were cultured on different bacteriological media, according to the type of sample. A. baumannii colonies on blood agar were smooth, grayish white, mucoid, non hemolytic and smaller than that of Enterobacteriacea, on MacConkey's and CLED agar were non lactose fermenting (pale) mucoid colonies.

\section{Microscopic examination:-}

Gram stained films were done from the growing colonies to detect Gram-negative coccobacilli.

\section{Antibiotic sensitivity testing:-}

Was done by the disk diffusion (Kirby-Bauer) method. Using Mueller-Hinton agar and group of commercially prepared antibiotic discs ${ }^{(9)}$.The antibiotic discs used were amikacin, amoxicillin, cefuroxime, cefotaxime, gentamicin, imipenem and meropenem ${ }^{(\mathbf{1 2})}$. 


\section{Modified Hodge Test:-}

The presence of a distorted inhibition zone around the imipenem disc after overnight incubation was interpreted as a positive Hodge test which indicated production of Metallo- B-lactemase (MBLs) ${ }^{(\mathbf{1 3})}$.

Detection of bla $a_{\text {Oxa-23 }}$ and bla

Multiplex PCR was done for the detection of the two families of OXA-type carbapenamases found in A.baumannii (14).

\section{DNA extraction:-}

Was done by using (Gene JET Genomic DNA Purification Kit, Thermo Scientific, For 50 preps, Lot. 00189391, The European Union (EU) Lithuania) according to manufacturer instructions.

\section{Amplification:-}

Sequences of primers were used for multiplex PCR for the detection of genes encoding bla $\mathrm{OXA}_{23}$ andbla OXA-58 $_{\text {genes. }}$.

\begin{tabular}{|l|l|l|}
\hline Primer & Primer sequence (5\-3\) & Product size (bp) \\
\hline blaOXA-23-F & GATCGGATTGGAGAACCAGA & 501 \\
blaOXA-23-R & ATTTCTGACCGCATTTCCAT & \\
blaOXA-58-F & AAGTATTGGGGCTTGTGCTG & 599 \\
blaOXA-58-R & CCCCTCTGCGCTCTACATAC & \\
\hline
\end{tabular}

PCR reaction was carried out in a final volume of $50 \mu \mathrm{L}$ containing $1 \mathrm{x}$ reaction buffer, $5 \mu \mathrm{L}$ of extracted DNA templete, $100 \mathrm{mM}$ each dNTP, $1 \mu \mathrm{L}$ of each primer and $1 \mu \mathrm{L}$ of Taq polymerase. Amplification was done as follows:

* Initial denaturation step: at $94^{\circ} \mathrm{C}$ for $15 \mathrm{~min}$.

* Three steps cycling: (33 cycles)

$\checkmark$ Denaturation:at $94^{\circ} \mathrm{C}$ for $25 \mathrm{Sec}$.

$\checkmark$ Annealing:at $53^{\circ} \mathrm{C}$ for $40 \mathrm{Sec}$.

$\checkmark$ DNA extension: at $72^{\circ} \mathrm{C}$ for $50 \mathrm{Sec}$.

* Final extension: at $72{ }^{\circ} \mathrm{C}$ for 6 min.

* The thermal cycler program was adjusted by using PTC-100TM Programmal Thermal Controller, Peltier-Effect Cycling, MJ.

Electrophoresis of the amplified products: ${ }^{(15)}$.

Ethidium bromide stained bands in agarose gel $(1.5 \%)$ were visualized on UV transilluminator and photographed. The expected bands were 501 bp for bla OXA-23 gene and 599 bp for bla OXA-58 gene in comparison to molecular size marker (100 bp DNA Ladder).

\section{Animal groups:-}

Mice (15 animals each weighing $25 \pm 3 \mathrm{~g}$ ) were randomly divided into three groups. The first group served as normal control. The second group was injected with $200 \mu \mathrm{l} / \mathrm{g}$ body weight of resistant A. baumannii strain. In the third group, mice were injected with $200 \mu \mathrm{l} / \mathrm{g}$ body weight of sensitive A.baumannii strain. The 3 groups were housed in the animal house of the Faculty of Science, Mansoura University.

\section{Sampling and preparation of tissue homogenate:-}

At the end of the study period 3 days after A.baumannii infection, all mice were placed individually in metabolic cages for $24 \mathrm{~h}$. Animals were overnight fasted then sacrificed under ether anesthesia by cervical dislocation. Blood samples were collected from each mouse, centrifuged at $2000 \mathrm{xg}$ for $15 \mathrm{~min}$, obtained sera were kept for biochemical analysis. The liver homogenization was done in ice cold saline solution and the homogenate was kept frozen at $-20^{\circ} \mathrm{C}$ until being analyzed, as soon as possible.

\section{Determination of liver functions and kidney functions:-}

Serum ALT, AST and bilirubin were detected using the method of Young ${ }^{(16)}$. Serum creatinine, urea, uric acid, sodium and potassium were detected using the methods of Schirmeister ${ }^{(17)}$, Fawcett and Soctt ${ }^{(18)}$, Barham and Tinder ${ }^{\mathbf{( 1 9 )}}$, Henry et al., ${ }^{(\mathbf{2 0})}$ and Sunderman ${ }^{(\mathbf{2 1 )}}$ respectively. 
Determination of antioxidants Glutathion (GSH), Superoxid Dismutase (SOD) and Catalase (CAT) levels:Were estimated using the methods of Prins and Loose ${ }^{(\mathbf{2 2})}$, Nishikimi et al. ${ }^{(\mathbf{2 3})}$ and Bock et al. ${ }^{(\mathbf{2 4})}$ respectively.

\section{Results:-}

Out of 1050 positive cultures of all nosocomial samples received, 44 (4.2\%) A.baumannii strains were isolated and characterized. A.baumannii strains were isolated from 15 urine (34.09\%), 13 blood (29.54\%), 10 sputum (22.73\%) samples and 6 septic wounds $(13.64 \%)$.

Antibiotic susceptibility:- Twelve (28\%) A.baumannii isolates were sensitive to imipinem, 29 (66\%) were meropenem sensitive and $22(50 \%)$ were sensitive to amikacin and no sensitivity was observed with Cefuroxime (Table 1).

Modified Hodge test:- Carbapenemase production was confirmed by Modified Hodge tests. Out of 44 A.baumannii isolates, $24(54.55 \%)$ were positive by Hodge test and $20(45.45 \%)$ were negative.

PCR results:- Multiplex PCR detected 32 (72.72\%) of the isolates carried bla ${ }_{\text {OXA-23 }}$ gene, while the bla OXA-58 $_{\text {gene }}$ was detected in $13(29.54 \%)$ of the isolates (Table 2).

The effect of $A$. baumannii infection on the excretory system and antioxidant levels in mice:- Statistically significant increase of liver function markers in serum of infected mice in group I infected with resistant A.baumannii strain in comparison to control group (ALT $\mathrm{P}<0.0001$, AST $\mathrm{P}<0.001$ and total bilirubin $\mathrm{P}<0.02$ ). (Table 3). Regarding the renal function test there were slight changes in the form decrease of creatinine and urea levels in the infected mice in comparison to the control group with no statistically significant change. There were no considerable change in $\mathrm{Na}^{+}, \mathrm{K}^{+}$, and Uric acid levels between different mice groups (Table 4). Also Statistically significant decrease of GSH $(\mathrm{P}<0.0001)$ and in activities of SOD $(\mathrm{P}<0.0001)$ and CAT $(\mathrm{P}<0.0001)$ were noticed in mice liver tissue of group I and group II in comparison to control group (Table 5).

Table 1: Antibiotic susceptibility pattern of 44 nosocomial A.baumannii strains.

\begin{tabular}{|l|c|c|c|c|c|c|}
\hline \multirow{2}{*}{ Antibiotics } & \multicolumn{4}{|c|}{ Total no. of strains = 44 } \\
\cline { 2 - 7 } & \multicolumn{2}{|c|}{ Sensitive strains } & \multicolumn{2}{c|}{ Intermediate strains } & \multicolumn{2}{c|}{ Resistant strains } \\
\cline { 2 - 8 } & No & $\%$ & No & $\%$ & No & $\%$ \\
\hline Amikacin (AK) & 22 & 50 & 10 & 23 & 12 & 27 \\
\hline Amoxycillin (AX) & 6 & 14 & 34 & 77 & 4 & 9 \\
\hline Gentamicin (CN) & 12 & 27 & 14 & 32 & 44 & 100 \\
\hline Cefuroxime (CXM) & 0 & 0 & 0 & 0 & 28 & 63 \\
\hline Cefotaxim (CTX) & 6 & 14 & 10 & 23 & 29 & 66 \\
\hline Imipenem (IPM) & 12 & 28 & 3 & 6 & 9 & 20 \\
\hline Meropenem (MEM) & 29 & 66 & 6 & 14 & 9 & 9 \\
\hline
\end{tabular}

Table 2: PCR results for 44 A.baumannii isolates.

\begin{tabular}{|c|c|c|c|c|}
\hline \multirow[t]{3}{*}{ Isolates } & \multicolumn{2}{|c|}{ bla $_{O X A-23}$} & \multicolumn{2}{|c|}{ bla $_{\text {OXA-58 }}$} \\
\hline & Positive & Negative & Positive & Negative \\
\hline & No & No & No & No \\
\hline Urine & 11 & 4 & 3 & 12 \\
\hline Blood & 9 & 4 & 5 & 8 \\
\hline Sputum & 7 & 3 & 3 & 7 \\
\hline Wound swabs & 5 & 1 & 2 & 4 \\
\hline Total Positive & \multicolumn{2}{|c|}{$32(72.72 \%)$} & \multicolumn{2}{|c|}{$13(29.54 \%)$} \\
\hline
\end{tabular}


Table 3:- Serum ALT, AST and total bilirubin in control group and A.baumannii. infected mice.

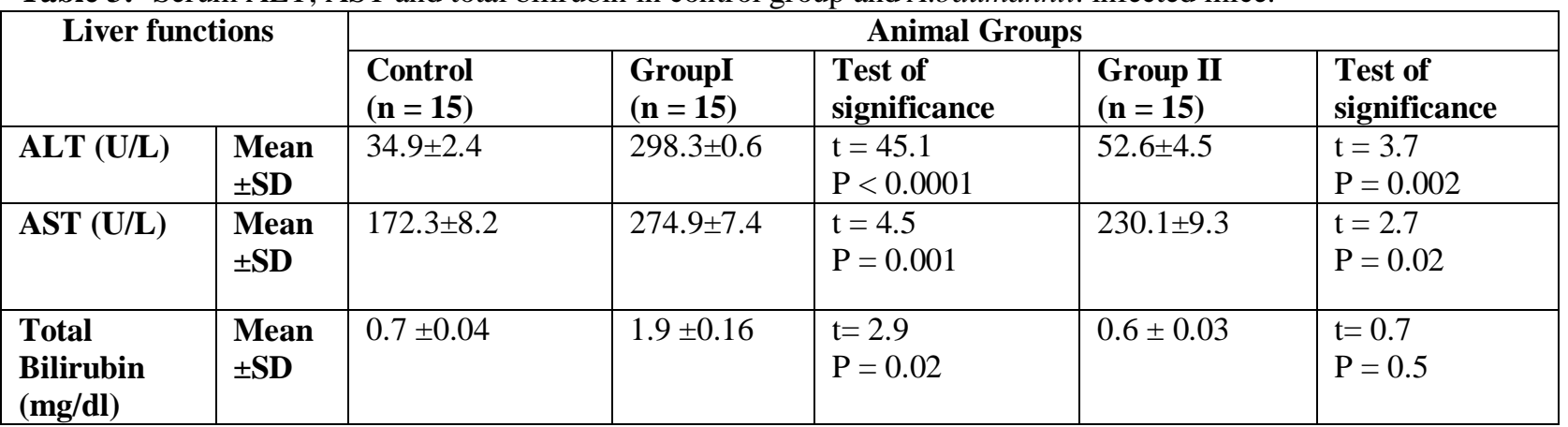

ALT:alanine aminotransferase and AST:aspartate aminotransferase

Table 4:- Serum kidney markers in control group and A.baumannii infected mice.

\begin{tabular}{|c|c|c|c|c|c|}
\hline \multirow{2}{*}{ Kidney functions } & \multirow{2}{*}{\multicolumn{2}{|c|}{$\begin{array}{l}\text { Group I } \\
(n=15)\end{array}$}} & & \multirow[b]{2}{*}{$\begin{array}{c}\text { Group II } \\
(\mathbf{n}=15)\end{array}$} & \multirow[b]{2}{*}{$\begin{array}{c}\text { Test of } \\
\text { significance }\end{array}$} \\
\hline & & & $\begin{array}{c}\text { Test of } \\
\text { significance }\end{array}$ & & \\
\hline $\begin{array}{l}\text { Cr }(\mathrm{mg} / \mathrm{dl}) \\
\text { Mean } \pm \text { SD }\end{array}$ & $0.69 \pm 0.03$ & $0.68 \pm 0.03$ & $\begin{array}{l}\mathrm{t}=0 \\
\mathrm{P}=1\end{array}$ & $0.6 \pm 0.03$ & $\begin{array}{l}\mathrm{t}=0.3 \\
\mathrm{P}=0.8\end{array}$ \\
\hline BU(mg/dl) Mean \pm SD & $23 \pm 0.6$ & $23.2 \pm 0.5$ & $\begin{array}{l}\mathrm{t}=0.03 \\
\mathrm{P}=1\end{array}$ & $21.2 \pm 0.5$ & $\begin{array}{l}\mathrm{t}=0.3 \\
\mathrm{P}=0.8\end{array}$ \\
\hline $\begin{array}{l}\text { UA(mg/dl) } \\
\text { Mean } \pm \text { SD }\end{array}$ & $3.8 \pm 0.4$ & $3.7 \pm 0.3$ & $\begin{array}{l}t=0.4 \\
P=0.7\end{array}$ & $3.9 \pm 0.4$ & $\begin{array}{l}t=0.3 \\
P=0.8\end{array}$ \\
\hline $\begin{array}{l}\mathrm{Na}^{+}(\mathrm{m} . \mathrm{Eq} / \mathrm{L}) \\
\mathrm{Mean} \pm \mathrm{SD}\end{array}$ & $147.2 \pm 5.9$ & $148.5 \pm 5.2$ & $\begin{array}{l}\mathrm{t}=0.4 \\
\mathrm{P}=0.7\end{array}$ & $147 \pm 5.02$ & $\begin{array}{l}\mathrm{t}=0.05 \\
\mathrm{P}=0.9\end{array}$ \\
\hline $\begin{array}{l}\mathbf{K}^{+}(\mathbf{m} . \mathbf{E q} / \mathbf{L}) \\
\text { Mean } \pm \text { SD }\end{array}$ & $5.7 \pm 0.45$ & $5.7 \pm 0.6$ & $\begin{array}{l}t=0.1 \\
P=0.9\end{array}$ & $6.3 \pm 0.7$ & $\begin{array}{l}t=1.8 \\
P=0.1\end{array}$ \\
\hline
\end{tabular}

Cr: creatinine, BU:blood urea, UA: Uric acid, $\mathrm{Na}^{+}$: Sodium and $\mathrm{K}^{+}$:Potassium.

Table 5:- liver glutathione contents, Superoxide dismutase activity and Catalase activity in tissue of control group and A.baumannii infected mice.

\begin{tabular}{|c|c|c|c|c|c|c|}
\hline & & $\begin{array}{l}\text { Control } \\
\mathrm{n}=15\end{array}$ & $\begin{array}{l}\text { Group I } \\
n=15\end{array}$ & $\begin{array}{l}\text { Test of } \\
\text { significance }\end{array}$ & $\begin{array}{l}\text { Group II } \\
\mathbf{n}=15\end{array}$ & $\begin{array}{l}\text { Test of } \\
\text { significance }\end{array}$ \\
\hline $\begin{array}{l}\text { GSH } \\
(\mathrm{mg} / \mathrm{g})\end{array}$ & $\begin{array}{l}\text { Mean } \\
\pm \text { SD }\end{array}$ & $\begin{array}{l}11.3 \\
\pm 0.5\end{array}$ & $\begin{array}{l}3.5 \pm \\
0.6\end{array}$ & $\begin{array}{c}t=22.6 \\
P<0.0001\end{array}$ & $\begin{array}{l}7.7 \pm \\
0.6\end{array}$ & $\begin{array}{l}\mathrm{t}=10.58 \\
\mathrm{P}<0.0001\end{array}$ \\
\hline SOD (U/g) & $\begin{array}{l}\text { Mean } \\
\pm \text { SD }\end{array}$ & $\begin{array}{l}420.3 \\
\pm 13.8\end{array}$ & $\begin{array}{l}254.3 \quad \pm \\
28.4\end{array}$ & $\begin{array}{l}\mathrm{t}=12.9 \\
\mathrm{P}<0.0001\end{array}$ & $\begin{array}{l}342.2 \\
17.5\end{array}$ & $\begin{array}{l}t=8.6 \\
P<0.0001\end{array}$ \\
\hline CAT, (U/g) & $\begin{array}{l}\text { Mean } \\
\pm \text { SD }\end{array}$ & $\begin{array}{r}782.7 \\
\pm 7.3\end{array}$ & ${ }^{* *} 649 \pm 14.6$ & $\begin{array}{l}\mathrm{t}=20.04 \\
\mathrm{P}<0.0001\end{array}$ & $\begin{array}{l}{ }^{* *} 705.5 \\
20.5\end{array}$ & $\begin{array}{l}\mathrm{t}=8.7 \\
\mathrm{P}<0.0001\end{array}$ \\
\hline
\end{tabular}

GSH: Glutathion. SOD: Superoxid Dismutase. CAT: Catalase

\section{Discussion:-}

A.baumannii is a Gram-negative bacterium associated with nosocomial infections. While this organism can be found in soil and water, there is evidence that the most of the recent infections are caused by strains that populate the hospital environment ${ }^{(25)}$.

Multi-drug resistant (MDR) A.baumannii clones are spread throughout many different geographic areas and treatment options for MDR A.baumannii infections are limited in most cases to carbapenems ${ }^{(\mathbf{2 6})}$.

The frequency of A.baumannii isolation in this study was $4.2 \%$ of all hospital pathogens, these results were in agreement with Seifert et al., (1995) who found that A.baumannii accounted for $4.6 \%$ of isolates ${ }^{\text {(27) }}$. Our results were not coordinated with the results obtained by Abul-Ella et al., (1997) who reported 7.9\% of Acinetobacter spp. among nosocomial isolates ${ }^{(28)}$. 
This study reported $12(28 \%)$ of A.baumannii were sensitive to imipinem and $29(66 \%)$ were sensitive to meropenem and $22(50 \%)$ of isolates were sensitive to amikacin. These results were in agreement with Corrêa et al., (2012) who found $28 \%$ of A.baumannii isolates were sensitive to imipinem but found $30 \%$ were sensitive to meropenem $^{(\mathbf{2 9})}$. On the other hand Unal and Garcia-Rodriguez, (2005) ${ }^{\mathbf{( 3 0 )}}$ registered $73.1 \%$ of A.baumannii isolates were susceptible to meropenem and $69.8 \%$ were susceptible to imipenem. In contrast to our results, Gales et al., (2001) ${ }^{\text {(31) }}$ reported $88 \%$ of Acinetobacter spp. were imipinem sensitive, and $87 \%$ of Acinetobacter spp. were meropenem sensitive.

A.baumannii have OXA-type carbapenemases enzymes (ß-lactamases bacterial enzymes) which is the main enzymes that catalyze the hydrolysis of B-lactam antibiotics and make A.baumannii resistant to carbapenems. The Modified Hodge test is a phenotypic method for detection of carbapenemases ${ }^{(32)}$. During our study we showed that $54.55 \%$ of A.baumannii isolates were positive for carbapenemase production by the modified Hodge test and 45.45 $\%$ were negative. Khajuria et al.,(2014) ${ }^{(\mathbf{3 3})}$ found $60 \%$ of A.baumannii isolates were positive by the modified Hodge Test, but Aksoy et al., (2015) ${ }^{\text {(34) }}$ observed $96 \%$ positive by the modified Hodge test among 52 A.baumannii strains. Carbapenem resistance occurred due to OXA type carbapenemases is a growing problem and metalo- $\beta$ lactamase production along with co- production of OXA enzymes are considered to be the important reason for resistance to imipinem in A.baumannii.

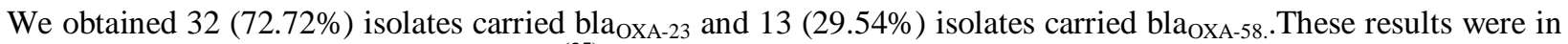
agreement with Quiñones et al., (2015) ${ }^{(\mathbf{3 5})}$ who found that, from 30 A.baumannii strains $76 \%$ were positive for bla OXA-23 $_{\text {gene and } 3 \% \text { were positive for bla }}$ OXA-58 by multiplex PCR, on the other hand, Shoja et al., (2013) ${ }^{(36)}$

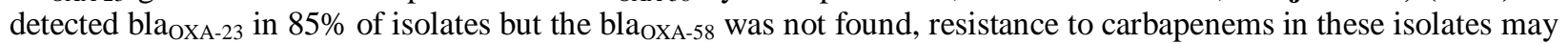
be related to other mechanisms including decreased permeability, alteration of penicillin-binding proteins, AmpC stable derepression and overexpression of efflux pump ${ }^{(37)}$.

The liver actively modulates inflammatory processes by filtering, inactivating and clearing bacteria and bacterial product e.g: endotoxin and the stimulated liver releases the highest amount of cytokines ${ }^{(9)}$. We found Statistically significant increase of liver function markers of infected mice in group I infected with resistant A.baumannii strain in comparison to control group [serum ALT $(\mathrm{P}<0.0001)$, AST $(\mathrm{P}=0.001)$ and total bilirubin $(\mathrm{P}=0.02)$ ]. These results were in agreement with Nesselere al., (2012) ${ }^{(\mathbf{8})}$ who found that serum total bilirubin, AST and ALT levels were significantly higher in infected rats than control rats after injection of rats with endotoxins of Salmonella anatum. As liver and spleen macrophages clear bacteria, viruses and endotoxins and they secrete chemical mediators and cytokines such as prostaglandins, leukotrienes, TNF- $\alpha$ that may leads to increase liver enzymes and bilirubin levels in the blood ${ }^{(8)}$.

Disturbance in the serum levels of creatinine, urea, $\mathrm{Na}^{+}$and $\mathrm{K}^{+}$may be as a result of disturbance of the filtration capacity of glomeruli due to dysfunction of the endothelium as a result of the production of pro-inflammatory humoral mediators by sepsis in kidney ${ }^{(38)}$. In addition, inflammatory mediators may lead to vasoconstriction and vasodilatation and no synthesis in septic shock which may affect kidney functions process ${ }^{(38)}$.

Antioxidant molecules work as scavengers, this way reducing Reactive oxygen species (ROS) bioavailability ${ }^{(39)}$. In the present study statistically significant decrease in GSH level $(\mathrm{P}<0.0001)$, SOD $(\mathrm{P}<0.0001)$ and CAT $(\mathrm{P}<$ 0.0001) activity in liver tissue after A.baumannii infection in comparison to control group. These results may be attributed to the role of sepsis in which liver dysfunction is considered an early event during sepsis and endotoxin injection resulted in membrane damage in the liver, which causes decrease levels of free radical scavengers and leads to an imbalance in the hepatic vasoregulatory gene expression, that causes reduced concentrations of GSH, as

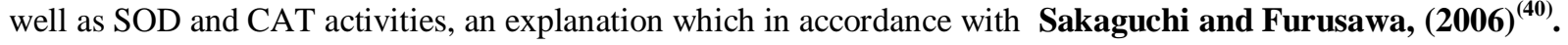

\section{In Conclusion:-}

The infection with A.baumanni causes damage of liver functions, renal functions and immune system which may lead to death so, the infection with this type of bacteria must be avoided in ICUs. This needs improving basic and extended knowledge on hygiene, the reinforcement of infection control measures, and the early detection, with restriction of the usage of carbapenems, to control the spread of these multidrug resistant organisms. 


\section{References:-}

1. Bergogne-Berezine, E, (2001): The increasing role of Acinetobacter species as nosocomial pathogens curr. infect, Dis. Rep. 3:444-448.

2. Othman A.B., Zribi, M., Masmoudi, A., Abdellatif, S., Lakhal, S.B., and Fendri, C. (2011): Multiresistance and endemic status of Acinetobacter baumannii associated with nosocomial infections in a Tunisian hospital: a critical situation in the intensive care units. Braz. J. Microbiol., 42 (2): 415-422.

3. Bergogne E, Towner KJ (1996): Acinetobacter spp. As nosocominal pathogens microbiological, clinical, and epidemiological features. Clin Microbiol Rev; 9 (2): 148-165.

4. Pachon J, Vila J, Treatment of multiresistant (2009): Acinetobacter baumanni infections. Curr Opin Investing Drugs, 10:150-156.

5. Nordmann, P., and Poirel, L. (2002): Emerging carbapenemases in Gram-negative aerobes. Clin. Microbiol. Infect., 8 (6): 321-331.

6. Peleg, A.Y., Seifert, H., and Paterson, D.L. (2008): Acinetobacter baumannii: emergence of a successful pathogen. Clin. Microbiol. Rev., 21: 538-582.

7. Queenan, A.M., and Bush, K. (2007): Carbapenemases: the versatile beta--lactamases. Clin. Microbiol. Rev., 20 (3): 440-458.

8. Nesseler N., Launey Y., Aninat C., Morel F., Yannick Mallédant Y., and Seguin P. (2012): The liver in sepsis. Bio. Med. Cent. Crit. Care, 16 (5): 235-242.

9. Dhainaut, J.F., Marin, N., Mignon, A. and Vinsonneau, C. (2001): Hepatic response to sepsis: interaction between coagulation and inflammatory processes. Crit. Care. Med., 29 (7): 42-47.

10. Thijs, A. and Lambert, G., (1998): Thijs. Pathogenesis of renal failure in sepsis. Kidney Int., 53 (66): S34-S37.

11. Victor, V. M., Rocha, M., Esplugues, J. V. and De la Fuente, M. (2005): Role of Free Radicals in Sepsis: Antioxidant Therapy. Curr. Pharmac. Des., 11 (24): 3141-3158.

12. Koneman, E.W., Allen, S.D., Janda, W.M., et al. (1997b): Antimicrobial susceptibility testing. In: Koneman EW, Allen SD, Janda WM, Schreckenberger PC and Winn WC (eds.). Col. Atl. and Text. Diag. Microbiol., Lippincott, Philadelphia., pp: 785-856.

13. Lee, K., Lim, Y.S., Yong, D., Yum, J.H., and Chong, Y. (2003): Evaluation of the Hodge Test and the Imipenem-EDTA Double-Disk Synergy Test for Differentiating Metallo B-Lactamase-Producing Isolates of Pseudomonas spp. and Acinetobacter spp. J. Clin. Microbiol., 41 (10): 4623-4629.

14. Mostachio, A.K., Heidjen, I.V., Rossi, F., Levin, A.S., and Costa, S.F. (2009): Multiplex PCR for rapid detection of genes encoding OXA and metallo-beta-lactamases in carbapenem resistant Acinetobacter spp. J. Med. Microbiol., 58:1552-1554.

15. Davis LG, Dibner MD and Baltey JF (1986): Agarose gel eletrophoresis. In: Davis LG, Dibner MD and Baltey JF (eds.) Basic methods in molecular biology. Elsevier Science publishing. New York. pp: 58-61.

16. Young, D.S. (2001): Effects of disease on Clinical Lab. Tests, 4th ed. AACC., (1,2): 189088345-X.

17. Schimeister, J. (1964): Determination of creatinine in serum, DSH,. Med. W. Schr., 89: 1940.

18. Fawcett, J. and Soctt, J.E. (1960): A rapid and precise method for determination of urea. J. Clin., Path., 13: $156-159$.

19. Barham, D. and Tinder P. (1972): Enzymatic determination of uric acid. Analyst., 97: 142-145.

20. Henry, R.F., Harper and Row, Hargersein, M.D. et al., (1974): Clinical Chemistry Principles and Technics. 2nd Ed.

21. Sunderman, F.W. (1958): A rapid rehable method for the serum potassium using tetra phenyl boron. Am. J. Clin. Pathol., 29: 95-103.

22. Prins, H.K and Loose, J.A. (1969): Glutathion in biochemical method in red cell genetics. Edited by Yunis, J.J., Academic Press., N.Y.D. London, PP: 126-129.

23. Nishikimi, M., Roa, N.A. and Yagi, K. (1972): Measurment of superoxide dismutase. Biophys. Res. Common., 46 (2): 849-854.

24. Bock, P.P., Karmer, R., and Paverka, M. (1980): A simple assay for catalase determination cell Biol. Monoger., 7: 44-74.

25. Towner, K.J. (2009):Acinetobacter: an old friend, but a new enemy. J. Hosp. Infect., 73 (4): 355-363.

26. Giordano A, Varesi P, Bertini A, et al.(2007): Outbreak of Acinetobacter baumannii producing the carbapenem-hydrolyzing oxacillinase OXA-58 in Rome, Italy. Microb Drug Resist; 13: 37-43. 
27. Seifert, H.M.D., Strate A., and Pulverer, G. M.D. (1995): Nosocomial bacteremia due to A.baumannii Clinical features, Epidemiology, and Predictors of Mortality., 74 (6): 340-349.

28. Abul-Ella, M.A., Zaghloul, W., Rizk, M.S., and Elmaadawy, M. (1997): Isolation and chaacterization of small plasmids encoding multiple drug resistance from Acinetobacter Hospitals strains. Egyp. J. Med. Microbiol., 6 (1,2): 205-212.

29. Corrêaa, L.L., Botelhob, L.A.B., Barbosab, L.C., Mattosb, C.S., Carballidoc, J.M., Castroc, C.L.T., Mondinob, P.J.J., Paulad, G.R., Mondinoa, S.S.B., Mendonc, C.R.V. and Souzaa, A. (2012): Detection of blaOXA-23 in Acinetobacter spp. isolated from patients of a university hospital. Braz j infect dis., 16 (6): $521-$ 526.

30. Unal, S., and Garcia-Rodriguez J. A., (2005): Activity of meropenem and comparators against Pseudomonas aeruginosa and Acinetobacter spp. isolated in the MYSTIC Program, 2002-2004. Diagn. Microbiol. Infect. Dis., 53 (4): 265-271.

31. Gales, A.C., Jones, R.N., Forward, K.R., Linares, J., Sader, H.S. and Verhoef, J. (2001): Emerging Importance of Multidrug-Resistant Acinetobacter Species and Stenotrophomonas maltophilia as Pathogens in Seriously Ill Patients: Geographic Patterns, Epidemiological Features, and Trends in the SENTRY Antimicrobial Surveillance Program. Acinetobacter and S. maltophilia in Sentry. Cid., 32 (2): S104-S113.

32. Lee, K., Chong, Y., Shin, H.B. et al. (2001): Modified Hodge and EDTA-disk synergy tests to screen metallobeta-lactamase-producing strains of Pseudomonas and Acinetobacter species. Clin. Microbiol. Infect., 7 (2): 88-91.

33. Khajuria, A., Praharaj, A.K., Kumar, M. and Grover, N. (2014): Molecular Characterization of Carbapenem Resistant Isolates of Acinetobacter baumannii in An Intensive Care Unit of A Tertiary Care Centre at Central India. Journal of Clinical and Diagnostic Research., 8 (5): 38-40.

34. Aksoy, M.D., Çavuşlu, S. and Tuğrul, H.M. (2015): Investigation of Metallo Beta Lactamases and Oxacilinases in Carbapenem Resistant Acinetobacter baumannii Strains Isolated from Inpatients. Balkan Med. J., 32 (1): 79-83.

35. Quiñones, D., Carvajal, I., Perez, Y., Hart, M., Perez, J., Garcia, S., Salazar, D., Ghosh, S., Kawaguchiya, M., Aung, M.S., and Kobayashi, N. (2015): High prevalence of blaOXA-23 in Acinetobacter spp. and detection of blaNDM-1 in A. Soli in Cuba: report from National Surveillance Program. New Microbe. and New Infect., 7: 52-56.

36. Shoja, S., Moosavian, M., Peymani, A., Tabatabaiefar, M.A., Rostami, S., and Ebrahimi, N. (2013): Genotyping of carbapenem resistant Acinetobacter baumannii isolated from tracheal tube discharge of hospitalized patients in intensive care units, Ahvaz, Iran. J. Microbiol., 4 (5): 315-322.

37. Kulah, C., Mooij, M.J., Comert, F., Aktas, E., Celebi, G., Ozlu, N., et al. (2010): Characterisation of carbapenem-resistant Acinetobacter baumannii outbreak strains producing OXA-58 in Turkey. Int. J. Antimicrob. Agents, 36: 114-118.

38. Tiwari and Vikrant, (2000): Sepsis and the Kidney J. Ind. Acadm., 5 (1): 44-54.

39. Dessauer, B.V., Bongain, J., Molina, V., Quilodrán, J., Castillo, R. and Rodrigo, R. (2011): Oxidative stress as a novel target in pediatric sepsis management. J. Crit. Care, 26 (1): 103e1-103e7.

40. Sakaguchi, S. and Furusawa S. (2006): Oxidative stress and septic shock: metabolic aspects of oxygenderived free radicals generated in the liver during endotoxemia. FEMS Immunol. Med. Microbiol., 47 (2): 167-177. 